\title{
PERMEABILITY AND VOLUMETRIC CHANGES IN COAL UNDER DIFFERENT TEST ENVIRONMENT
}

\author{
Naj AZIZ *, Ting REN, Jan NEMCIK and Lei ZHANG \\ School of Civil, Mining and Environmental engineering, Faculty of Engineering, \\ University of Wollongong, Wollongong, Australia, 2522 \\ *Corresponding author's e-mail: naj@uow.edu.au
}

(Received July 2012, accepted March 2013)

\begin{abstract}
Permeability refers to the ability of coal to transmit gas when a pressure or concentration gradient exists across it. The permeability of coal is dependent upon factors that include effective stress, gas pressure, water content, disturbance associated with drilling and matrix swelling/shrinkage due to adsorption/desorption. A programme of laboratory tests were conducted on coal samples from the Bulli seam for evaluating the permeability and drainability of coal. Two different types of permeability apparatus were used in this study. The methods of permeability testing of coal under different triaxial conditions are discussed. Permeability testing of the Bulli seam coal with $\mathrm{N}_{2}$ is described. The laboratory test results were found to be in agreement with the calculated permeability values.
\end{abstract}

KEYWORDS: coal mine gas, coal permeability, volumetric changes

\section{INTRODUCTION}

Permeability is considered by many researchers to have a significant impact on a coal seam's ability to produce gas (Jones et al., 1982; Osisanya and Schaffitzel, 1996; Zutshi and Harpalani, 2005 and Lamarre, 2007). Permeability, which is closely related to the coal fabric (i.e. cleat spacing and aperture width), varies significantly as fluid pressure changes during coal seam gas production (Cui and Busten, 2006). Permeability has a strong effect on the gas production profile and gas well performance.

Permeability measurement results, tested in small coal samples in laboratory conditions, have been shown to be different from in situ measured values. Testing at Leichhardt Colliery, Gray (1982) found that, the measured core sample permeability was less than $5 \mathrm{mD}$, whereas the bulk permeability was found to be in the order of $200 \mathrm{mD}$, along the cleat. This clearly indicates that more research is needed to focus on the accuracy of different measuring methods and the relationship between the laboratory permeability results and in situ coal permeability result.

A number of different permeability testing apparatus have been reported. They are basically triaxial cells, which simulate the in situ conditions. Some apparatus consists of a conventional triaxial cell, modified to provide gas inlet and exist ports through the upper and lower platens, Harpalani and Schraufnagel (1990), while others are more elaborate in design, such as those reported by Lingard et al. (1982), Lama (1995), Gillies et al. (1995) and Nakajima et al. (1995). The mode of permeability testing, using these different apparatus however, can vary with respect to the way and role of the confinement pressure application.
A recent study by Black (2012) examining factors contributing to effective drainage of gas from coal found significant lack of information or insufficient level of data on coal permeability in comparison to other parameters such as gas content estimation and proximate analysis values. Black's study was based on studies of data collected from more than ten mines in Australia. Difficulties associated with permeability determination in the laboratory or in the field experimentation, are mainly due to the fact that both the laboratory and field tests raise concerns about the test method. The laboratory tests are generally carried out on competent core samples, not truly representative of the real in situ condition, while field tests, though yielding representative results, intrude on a mine's operation and production.

In order to obtain representative permeability values with respect to effective gas drainage from the difficult to drain zone and permit a better understanding of the potential gas recovery through nitrogen injection and displacement process, a laboratory permeability testing programme was initiated by the gas research group of the University of Wollongong. The programme consisted of duplicate testing of coal using two different permeability testing apparatus.

Both tests were carried out under triaxial test conditions. The first permeability testing method was carried out using a Multi Function Outburst Research Rig (MFORR) which was previously reported by Lama (1995), Aziz and Li (1999) and Sereshki (2005), and more recently by Zhang (2013). In this test, the sample was enclosed in a triaxial gas chamber. The coal sample was subjected directly to gas as the 
confining pressure. The pressured gas was made to filter through the coal sample while it is being loaded axially. A centrally drilled hole in the coal sample allowed the gas to flow out of the chamber in a controlled manner. The second permeability testing apparatus used in this study, was a high pressure triaxial cell, initially built for determining the relative permeability of coal measure rocks under two-phase flow conditions (Indraratna and Haque, 1999; Jasinge et al., 2011; Perera et al., 2011). Both methods of testing and the results obtained are the subject of discussion in this paper.

\section{GEOLOGY}

The experimental study of $\mathrm{N}_{2}$ injection was carried out on coal samples obtained from different mines operating in the Bulli Seam. The Bulli seam is stratigraphically the uppermost seam in the Illawarra coal measures, of Sydney Basin, which belong to Permian and Triassic era. It lies at variable depth ranging between $350 \mathrm{~m}$ in the east, near the coast areas, down to $550 \mathrm{~m}$ to the west with a regional dip of approximately $1.5^{\circ}$ toward the west and north west. The Bulli coal is high quality coking coal with volatile matters ranges from 18-23 percent (air dried), the ash level varies between 8-10\% (air dried), and the sulphur content is low at around 0.3 percent, the mineral content averages around $4 \%$. The vitrinite content is moderate at $45 \%$, the inertinite content is about $50 \%$ and vitrinite reflectance at around 1.3. The permeability of coal varies between 0.5 to $6.0 \mathrm{mD}$. The permeability values were determined both in situ and in the laboratory (Lingard et al., 1982; Sereshki, 2005; Black and Aziz, 2010). The permeability of the Bulli coal varies with low permeability zones characterized as being hard to drain with high concentration of $\mathrm{CO} 2$ gas. No attempt is made to report on the permeability coefficient by mathematical modeling characterising transmission and transport properties of gas, and flow character, as it beyond the scope of this paper.

The Bulli coal seam gas composition varies significantly throughout the Illawarra Coalfield, with the depth of cover and proximity to geological structures (faults and dykes). The changes in seam gas from predominantly $\mathrm{CH}_{4}$ to predominantly $\mathrm{CO}_{2}$ have been noted on a regional basis. Generally $\mathrm{CO}_{2}$ increases to the north and to the west. The high $\mathrm{CO}_{2}$ gas composition area with various gas content in a specific mine site was reported recently by Zhang et al., (2013). However, for each mine operating the Bulli seam in the Illawarra Coal measures, the potential gas composition to vary considerably is well recognised. The maximum desorbable gas content varies from $1-3 \mathrm{~m}^{3} / \mathrm{t}$ in the coastal areas in the east, to about $21 \mathrm{~m}^{3} / \mathrm{t}$ at depths of up to $550 \mathrm{~m}$ towards the west and north west.

The gas content and gas composition of the Bulli seam of the area varies within wide limits. In the seam closer to the outcrop, the gas content is relatively low.
As the distance from the outcrop increase, the gas content increases. The maximum desorbable gas content as measured in the coal seam varied between $1-3 \mathrm{~m}^{3} / \mathrm{t}$ in the coastal areas at a depth of $350 \mathrm{~m}$ and as much as $21 \mathrm{~m}^{3} / \mathrm{t}$ at greater depths of up to $550 \mathrm{M}$. The composition of the gas varies widely too. Normally the gases associated with the Bulli seam include both $\mathrm{CH}_{4}$ and $\mathrm{CO}_{2}$.

\section{COAL PERMEABILITY TEST WITH MULTI FUNCTION OUTBURST RESEARCH RIG (MFORR)}

\subsection{APPARATUS}

The Multi function Outburst Research Rig (MFORR) shown in Figure 1, was used to study the permeability of coal from parallel to its stratification. MFORR comprises a number of components which can be utilised for permeability testing with the confining pressure being provided by the applied gas pressure which filters through the coal being tested. As a multifunction apparatus the MFORR has various components:

- The main apparatus support frame

- A precision drill

- A high pressure chamber which has a load cell for measuring the load applied to the samples of coal

- A pressure transducer for measuring the pressure inside the chamber

- Flow meters for measuring the gas flow rate

- Two strain gauges for measuring the vertical and horizontal strains of the coal sample

- A universal socket for loading a sample of coal vertically into the gas pressure chamber

- A gas chromatograph (GC)

- A data acquisition system

\subsection{COAL SAMPLE PREPARATION}

Prior to coring, a lump of coal sample from a local mine operating the Bulli seam of Sydney Basis, of NSW, was cast in concrete to form a uniform block for easy coring. A set of standard core samples with a dimension of $54 \mathrm{~mm}$ in diameter and $50 \mathrm{~mm}$ in height were bored out of the coal block. A $2 \mathrm{~mm}$ diameter hole was drilled in the middle of the cored coal sample to measure the permeability of this apparatus. Prior to testing, both parallel ends of the prepared coal specimen were sealed with an adhesive, $1 \mathrm{~mm}$ thick, rubber layer to ensure effective gas flow along radius in the coal. Figure 2 shows the snapshot of the sample.

\subsection{TESTING PROCEDURE}

The procedure adopted for permeability test consisted of each sample being first mounted in the pressure chamber. The chamber was then sealed, the system then evacuated to remove air and subsequently repressurised to a predetermined level and maintained 


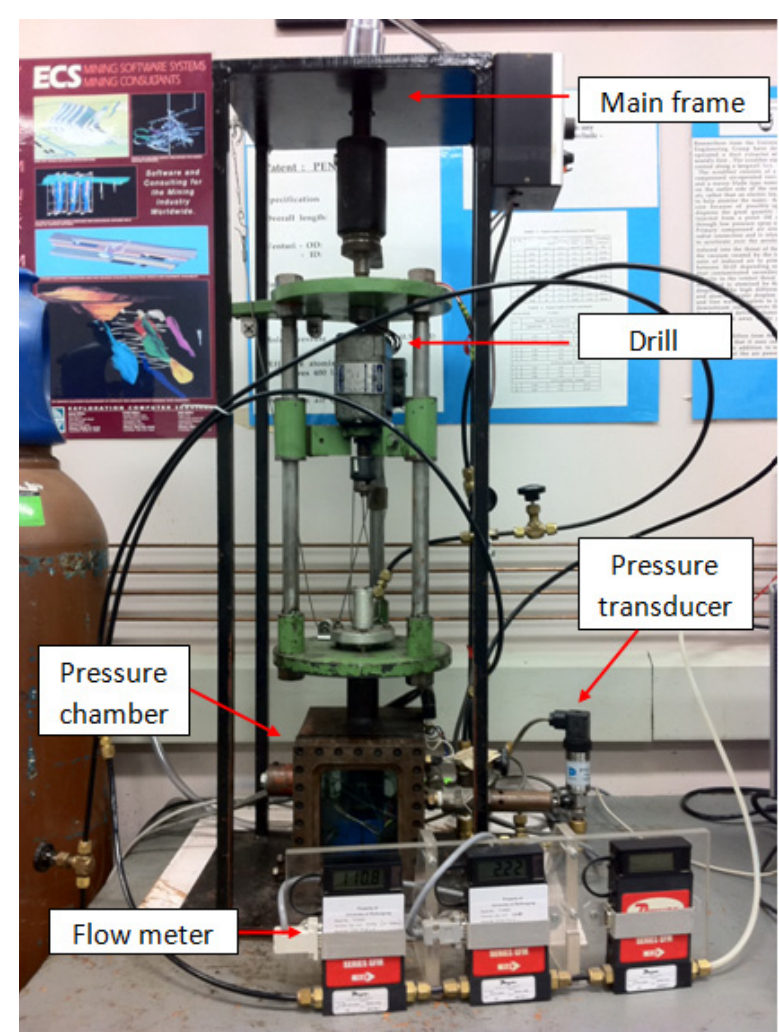

(a)

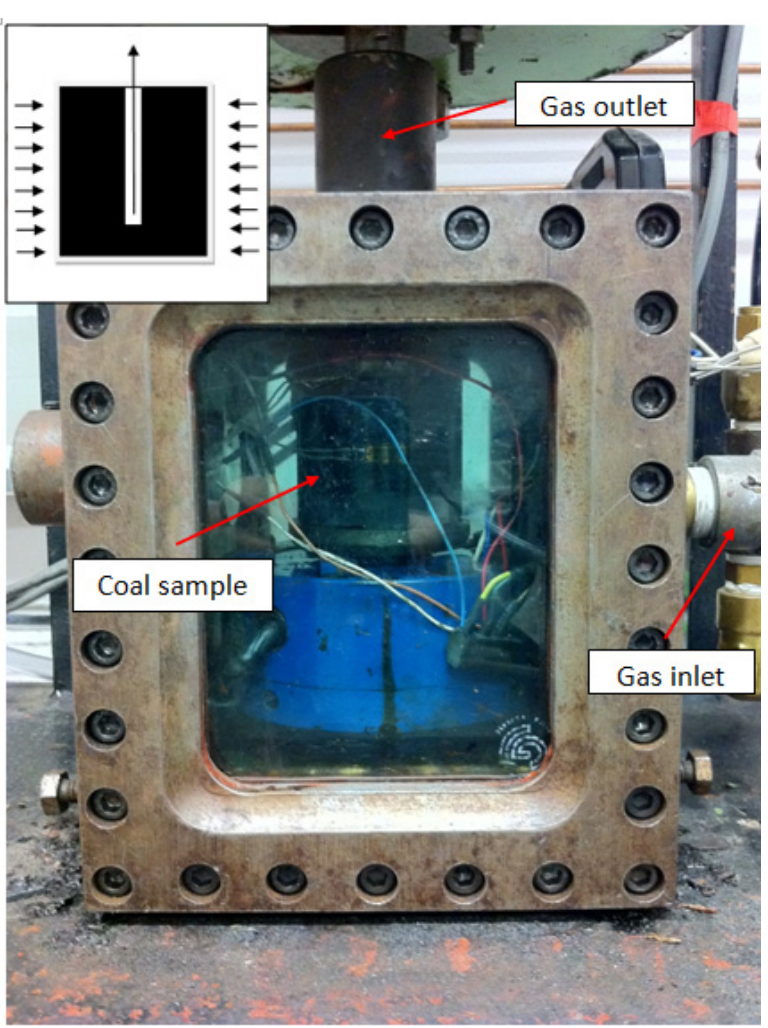

(b)

Fig. 1 Multi Function Outburst Research Rig (MFORR).

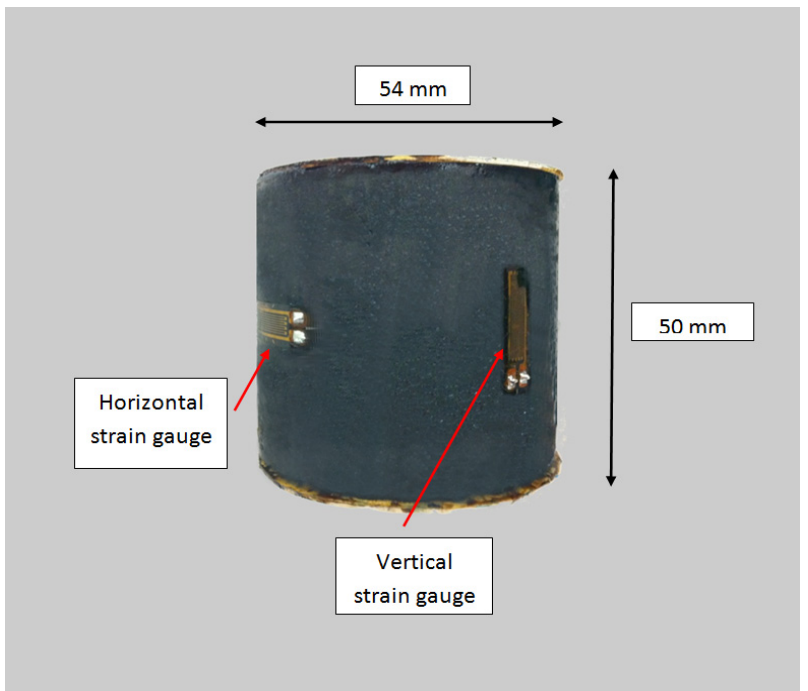

(a)

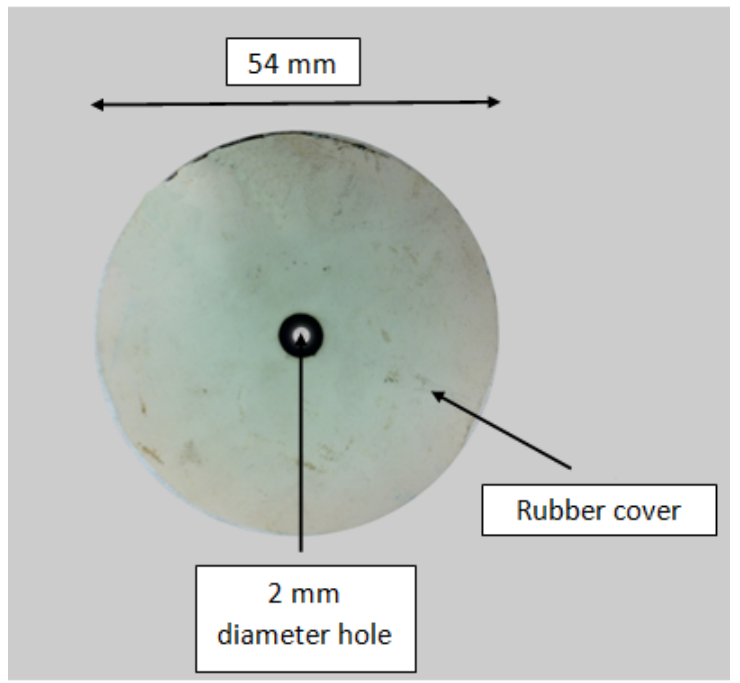

(b)

Fig. 2 Coal samples for permeability test with MFORR.

steady at that level. $\mathrm{N}_{2}$ gas was then allowed to permeate the coal sample and flow out through the central hole which is shown in Figure 1b. The released gas from the coal flows through a measuring system, consisting of a vacuum pressure sensor and a line of gas flowmeters of $0-2 \mathrm{~L} / \mathrm{min}$ and $0-15 \mathrm{~L} / \mathrm{min}$ measurement ranges respectively.
The test sequence was followed in steps of varying vertical stress of 1, 2, 3 and $4 \mathrm{MPa}$. For each selected vertical loading, confining gas pressures, varying between $0.2 \mathrm{MPa}$ to $3 \mathrm{MPa}$ were applied. The load cell, flowmeters, pressure transducer and strain gauges were connected to a PC through a data logger for data collection. 


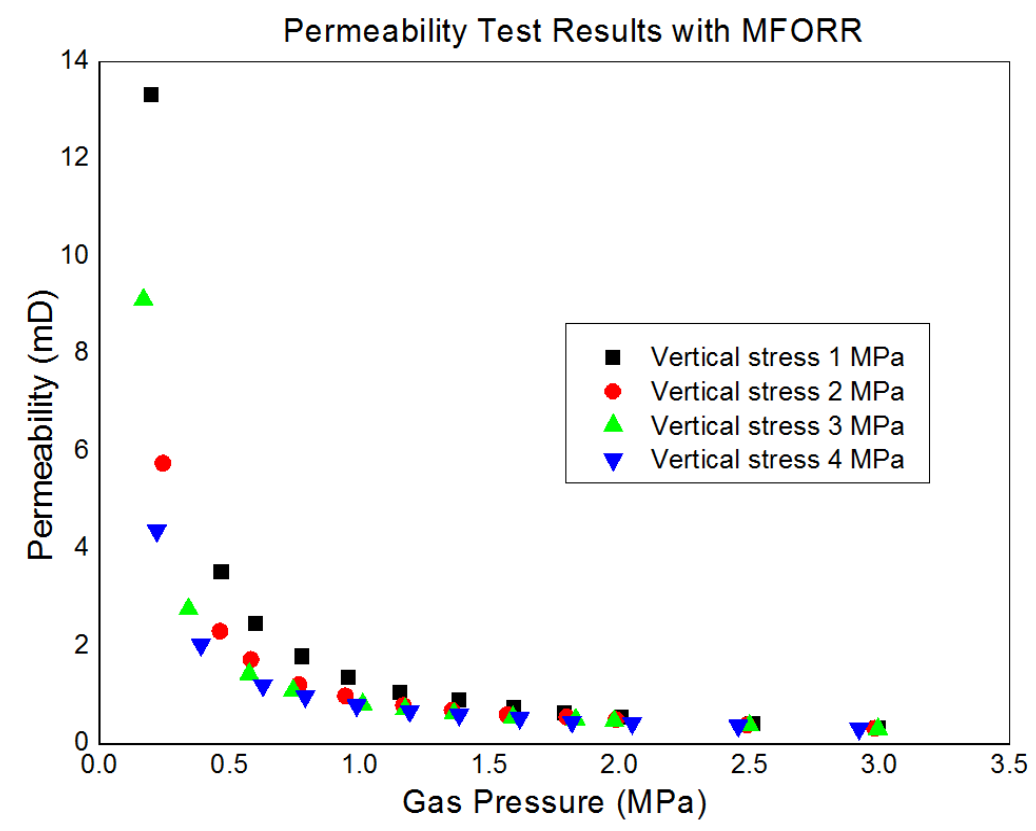

Fig. 3 Coal permeability test result with MFORR.

\subsection{TESTING RESULTS AND ANALYSIS}

The permeability of the coal sample was calculated using the following Darcy's equation:

$$
K=\frac{\mu Q \ln \left(\frac{r_{o}}{r_{1}}\right)}{\pi L\left(P_{1}^{2}-P_{2}^{2}\right)}
$$

Where $\mathrm{K}$ is the permeability of coal, $\mu$ is the viscosity of gas, $\mathrm{Q}$ is the flow rate of gas, $\mathrm{L}$ is the height of the sample, $r_{o}$ and $r_{i}$ are the external radius and internal radius of sample, $\mathrm{P}_{1}$ and $\mathrm{P}_{2}$ are absolute gas pressure inside and outside of chamber, respectively.

Figure 3 shows the permeability test result with MFORR apparatus, which is being pressurised by $\mathrm{N}_{2}$ gas, at different applied vertical stress levels. For each of the vertical stress level, the coal sample permeability decreases with increasing gas pressure and at higher gas pressure, coal permeability stays stable and changes very little, under different vertical stresses. The test results show that the permeability values stay below $2 \mathrm{mD}$ when the applied confining gas pressures became greater than $0.5 \mathrm{MPa}$.

Figure 4 shows coal strain behaviour in the MFORR permeability test. Test results show that the degree of strain, both axially and laterally, is influenced by the level of pressure that the sample being subjected to under triaxial environment.

There is an increased compaction of the coal layers parallel to bedding with increased vertical stress due to applied axial loads perpendicular to layering. The degree of axial shrinkage has increased with increasing axial stress as demonstrated in Figure 4a. Also, the level of vertical or axial strain reduction has reduced with the increase in the applied lateral gas confining pressure. The level of lateral/horizontal strain was affected by the level of the applied axial load as well as the confining gas pressure, this time in reverse order. That is, at high vertical stress of $4 \mathrm{MPa}$, the confining lateral stress was the greatest, while the least applied axial stress contributed to increased maximum lateral strain. Also and irrespective of the level of the axial stress the horizontal stain levels tapered off gradually with gradual increase of the applied confining gas pressure as demonstrate in Figure $4 b$.

These results clearly demonstrate the coal sample undergoing negative volumetric changes or shrinkage with increased confinement pressures axially and laterally, and that the degree of the volumetric changes will be dependent on the level of the applied axial and lateral pressures or stresses.

\section{TRIAXIAL PERMEABILITY STUDY WITH TRIAXIAL COMPRESSION APPARATUS \\ 4.1. APPARATUS}

The setup of the triaxial compression apparatus is shown in Figure 5. This apparatus, which can be utilised in normal triaxial permeability test of coal, comprises a number of components, including:

- A main apparatus loading system for holding and loading the pressure cell

- High pressure cell for holding the coal sample in triaxial permeability test

- A axial loading and measuring device

- Oil pump for generating and maintaining the confining pressure applied to the coal sample

- A pressure transducer for measuring the pressure inside the cell

- A pressure transducer for measuring the pore pressure 


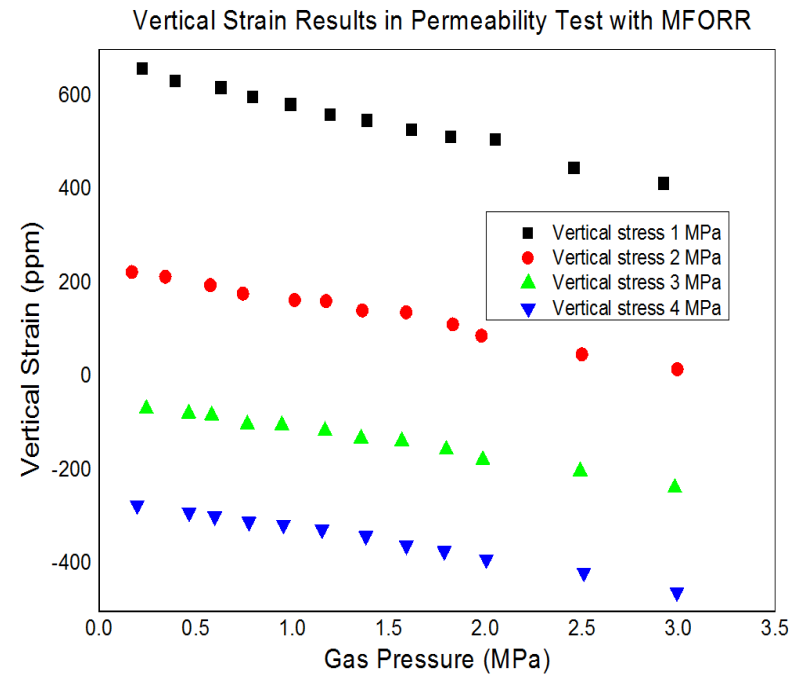

(a)

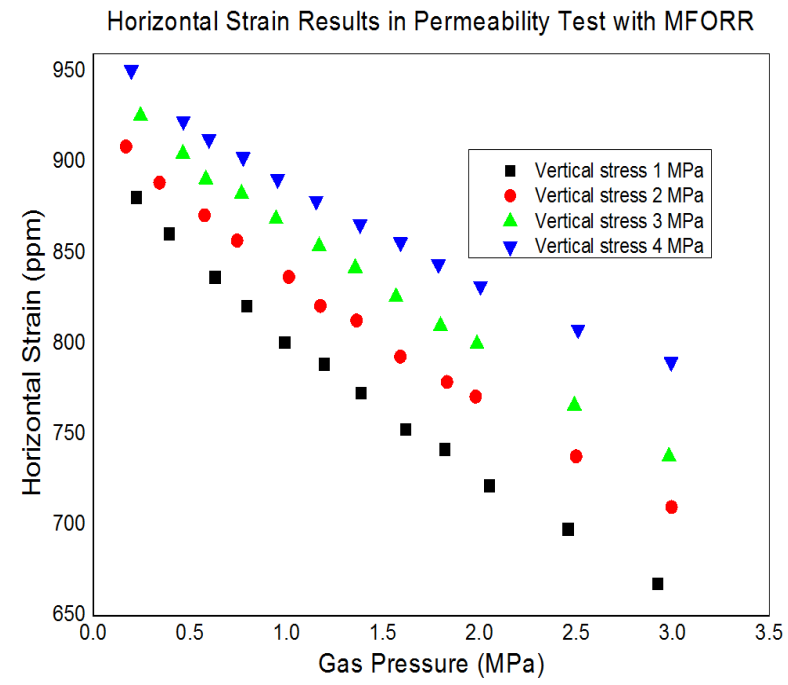

(b)

Fig. 4 Coal strain behaviour in the permeability test with MFORR.

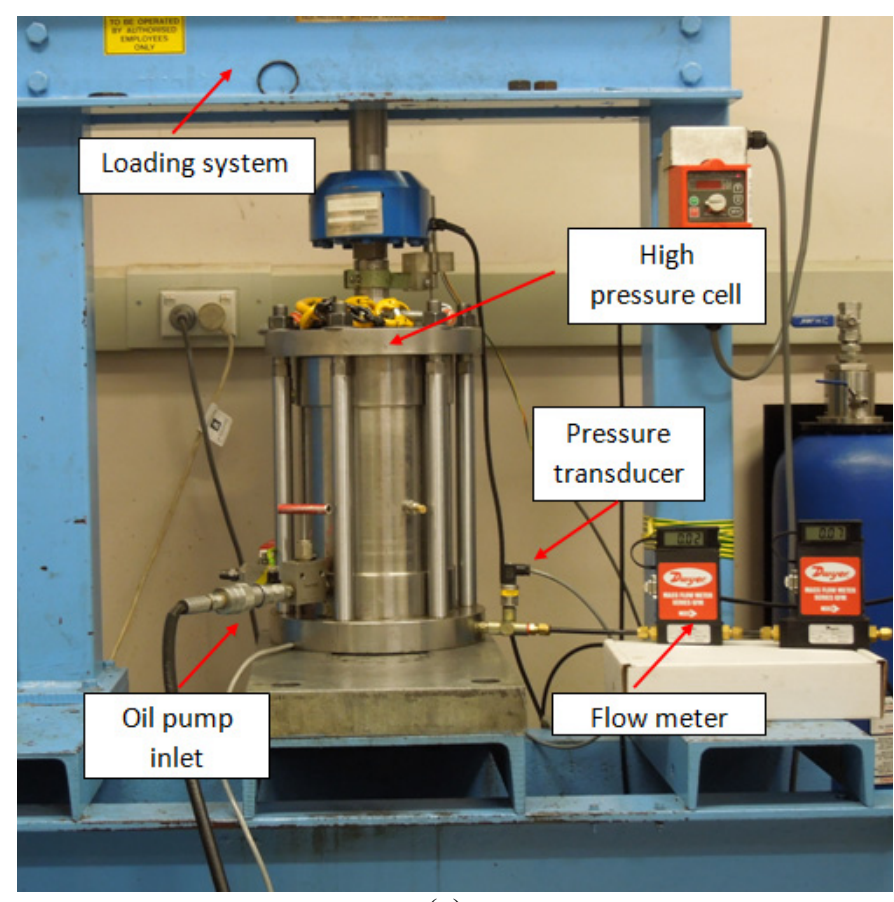

(a)

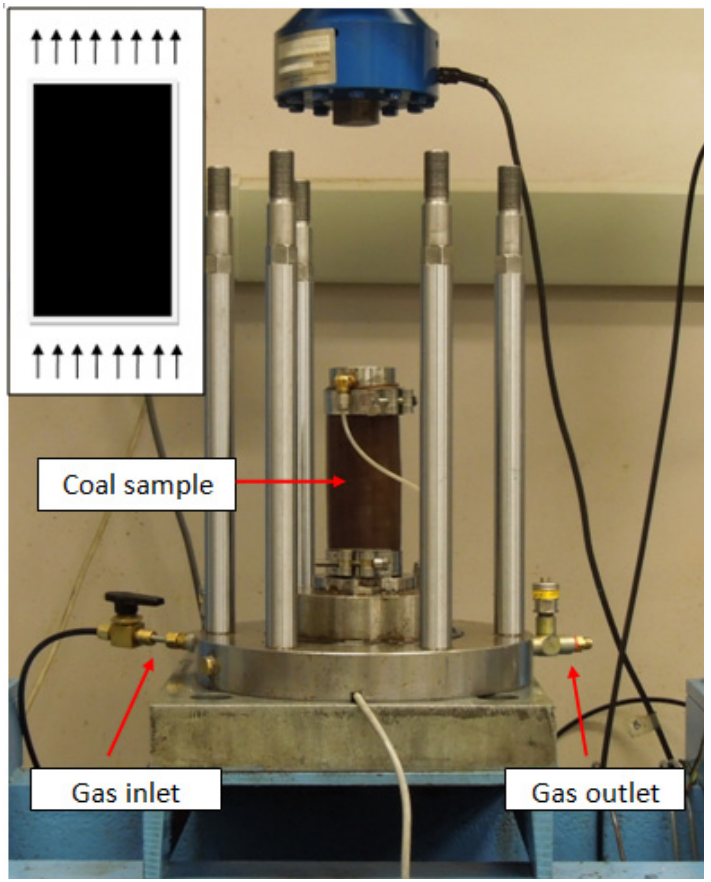

(b)

Fig. 5 Triaxial Compression Apparatus.

- Flow meters for measuring the gas flow rate

- A data acquisition system

In this apparatus, the cell pressure is controlled manually by a hydraulic jack and a pressure transducer, which is moučteld on the cell to ensure the required confining pressure. As the cell is made of high-yield steel it can withstand a maximum pressure of $150 \mathrm{MPa}$ with a safety factor of two. The cell is capable of carrying out high confining pressure tests, making it suitable to simulate a high in situ stress environment in coal measure rocks. The axial load is applied by a servo-controlled compression testing machine with the maximum force of $250 \mathrm{kN}$.

\subsection{COAL SAMPLE P||REPARATION}

The standard core samples with dimension of $54 \mathrm{~mm}$ in diameter and $100 \mathrm{~mm}$ in height were drilled from the same lump coal sample as the MFORR permeability test samples, which were also typical Bulli seam coal samples.

\subsection{TESTING PROCEDURE}

The procedure for conducting each test consisted of the sample being correctly installed inside a membrane, the specimen was placed into the high pressure cell where a small axial load was applied firstly to keep it stable; then oil was pumped into the cell until 


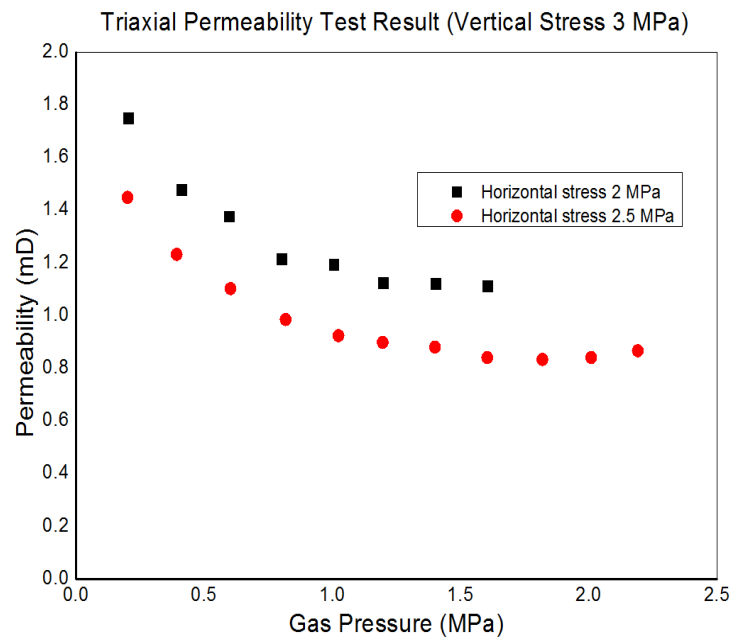

(a)

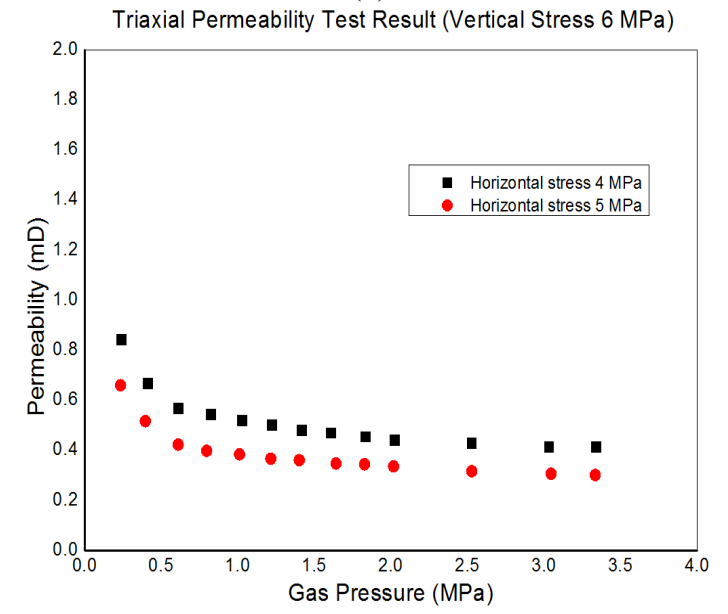

(c)

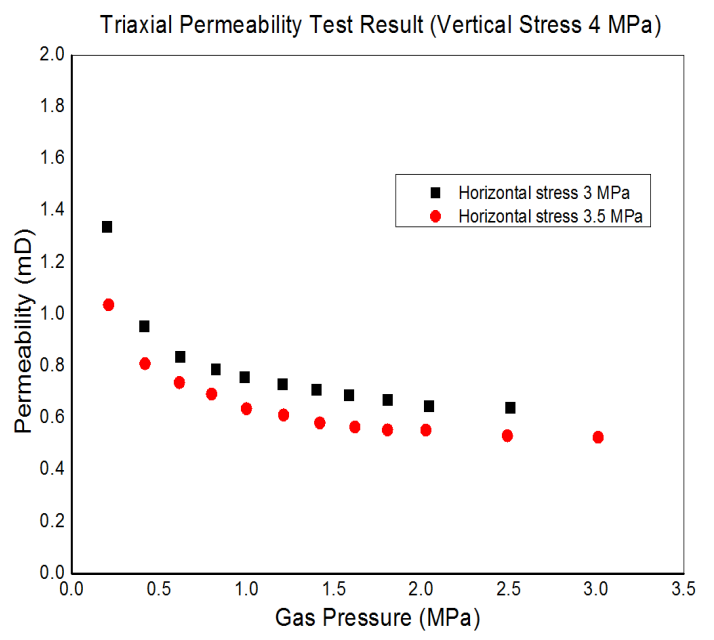

(b)

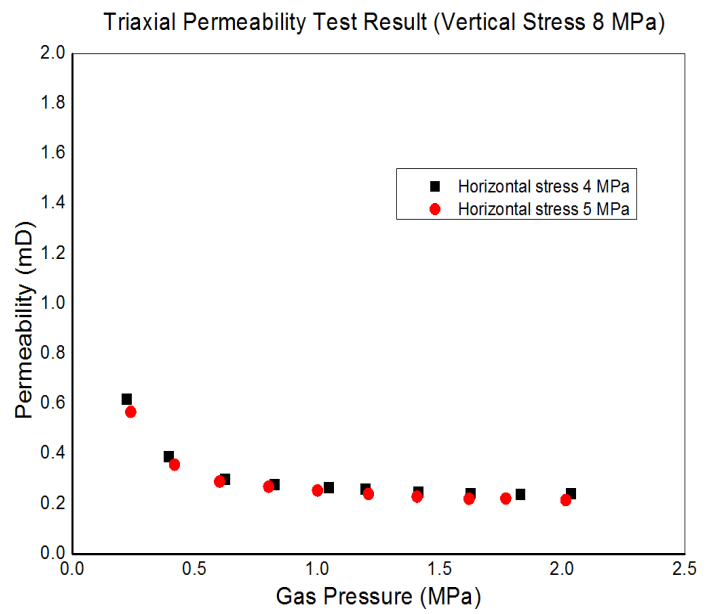

(d)

Fig. 6 Coal triaxial permeability test with a certain vertical stress.

the cell was filled with oil with both the axial load and confining pressure applied at predesigned values. Subsequently $\mathrm{N}_{2}$ gas pressure was applied at a predetermined level and $\mathrm{N}_{2}$ gas flowed through the coal sample from bottom to top, which was shown in Figure 5b. The released gas from the coal flowed through a monitoring system consisting of gas flowmeters with $0-2 \mathrm{~L} / \mathrm{min}$ and $0-15 \mathrm{~L} / \mathrm{min}$ measurement ranges.

The test sequence was followed in steps, with different vertical stresses of 3, 4, 6 and $8 \mathrm{MPa}$ respectively. The gas pressure was charged initially at $0.2 \mathrm{MPa}$ then increased gradually to higher pressure in steps reaching a maximum of $3 \mathrm{MPa}$. The load cell, flowmeters, a pressure transducer were all connected to a PC through a data logger for data collection.

\subsection{TESTING RESULTS AND ANALYSIS}

The permeability of the sample was calculated using the following Darcy's equation:

$$
K=\frac{2 Q \mu L P_{2}}{A\left(P_{1}^{2}-P_{2}^{2}\right)}
$$

Where $\mathrm{K}$ is the permeability of coal, $\mu$ is viscosity of gas, $\mathrm{Q}$ is the flow rate of gas, $\mathrm{L}$ is the length of the sample, A is the cross section of specimen, P1 and P2 are the inlet and outlet absolute gas pressure, respectively.

Figure 6 shows the triaxial permeability test results with $\mathrm{N}_{2}$ at different vertical stresses. Tests with a vertical stress of 3, 4, 6 and $8 \mathrm{MPa}$ were examined. For each of the vertical stress, two horizontal stresses were examined, coal sample permeability decreased with the increasing gas pressure. At higher gas pressures, coal permeability stayed constant, a similar trend as with the permeability test with MFORR. At each vertical stress, coal permeability test decreases with the increasing horizontal stress.

Figure 7 shows the triaxial permeability test results at a certain horizontal stress. Tests at horizontal stress of 4 and $5 \mathrm{MPa}$ are analysised in this study. At each of the horizontal stress, coal sample permeability decreases with the increasing vertical stress. It can be observed from the tests that the permeability values are well below $2 \mathrm{mD}$ under the triaxial test conditions. 


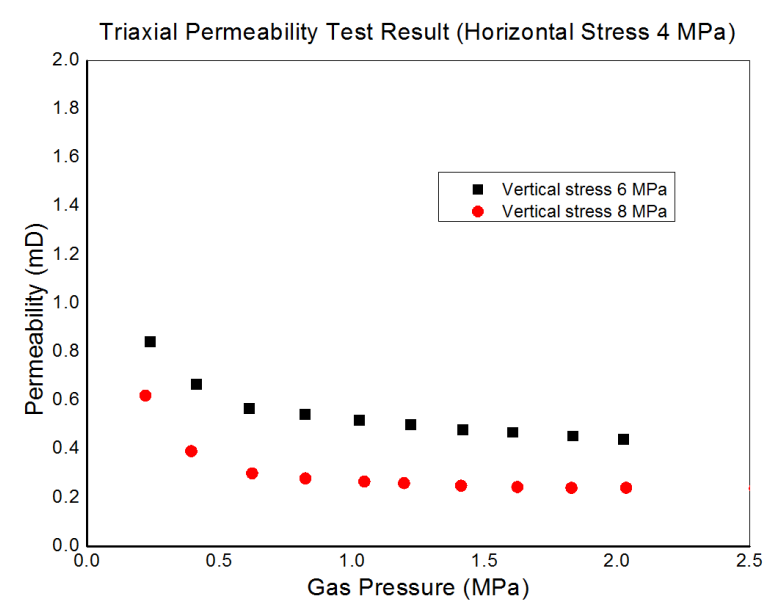

(a)

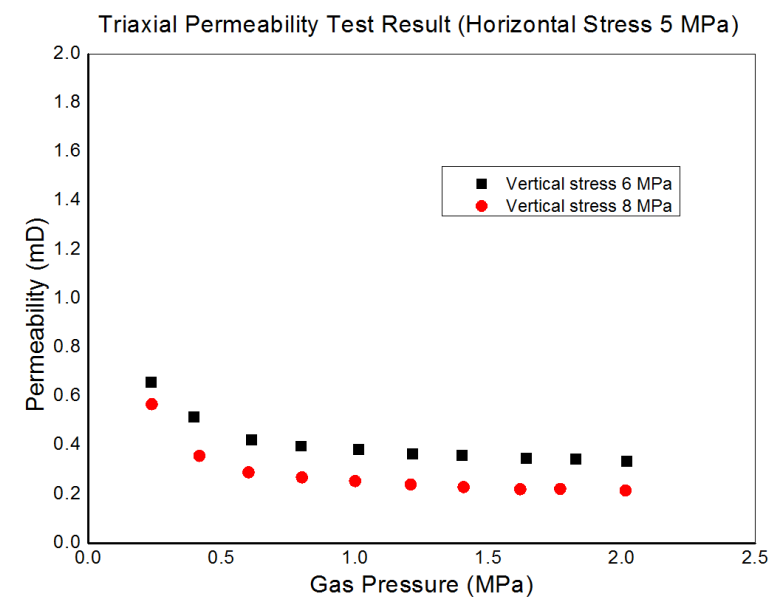

(b)

Fig. 7 Coal triaxial permeabilitv test with a certain horizontal stress.

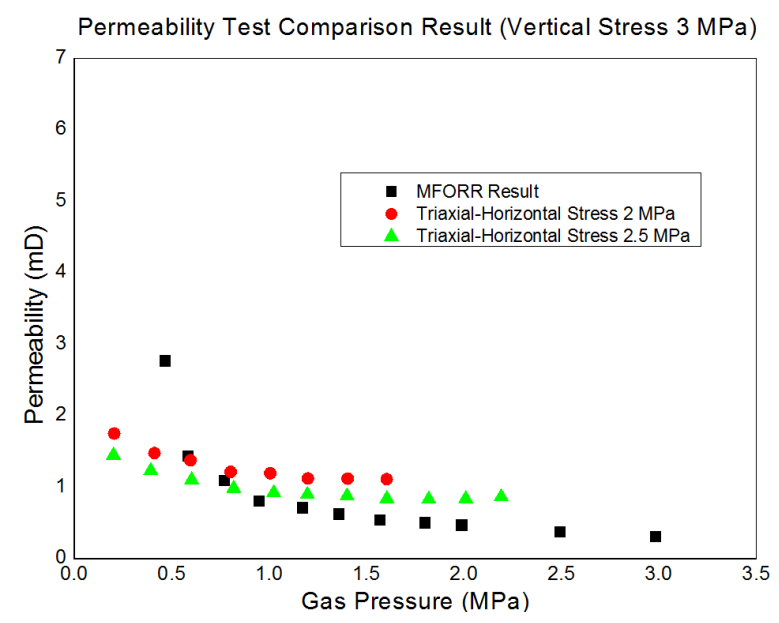

(a)

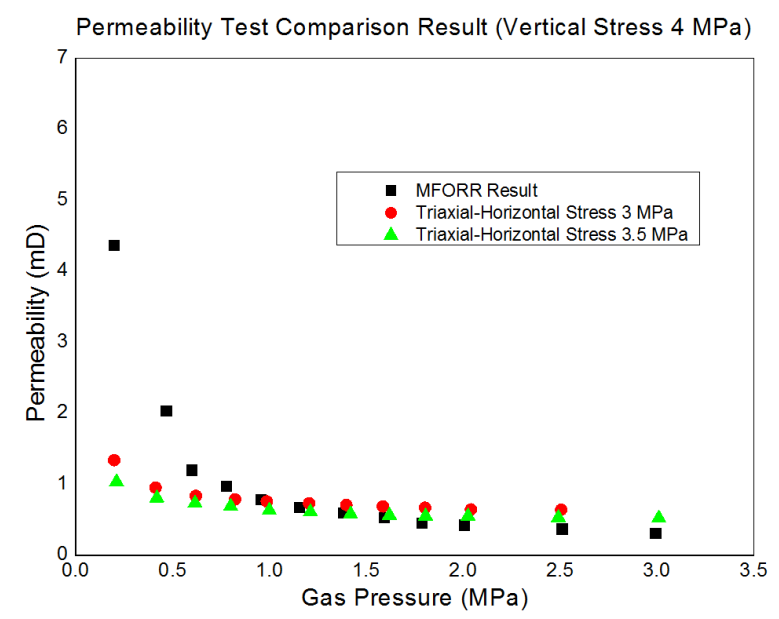

(b)

Fig. 8 MFORR permeability and triaxial permeability test results comparison.

\section{MFORR PERMEABILITY AND TRIAXIAL PERMEABILITY TEST RESULTS COMPARISON}

Figure 8 shows a comparison of the permeability results between the MFORR and triaxial tests at various vertical stresses. Although the results show some significant difference in permeability values at lower confining gas pressure because of the relatively low confining pressure of MFORR test, the permeability converges to a steady level below $2 \mathrm{mD}$ under high triaxial stress conditions, portraying the near in situ conditions of the Bulli seam. No significant mathematical difference between the two different types of testing apparatus and calculation method were evident.

Similar results are confirmed with the other studies; Hayes (1982) reported that the Bulli seam coal permeability was considerably less than $1 \mathrm{mD}$. Lingard et al. (1982) reported permeability of
Australian coals from Appin, West Cliff and Leichhardt collieries that varied from less than $0.1 \mathrm{mD}$ to $100 \mathrm{mD}$. Recently the Bulli seam coal permeability was measured using a combination of injection / falloff and step-rate testing methods (Jackson, 2004) and the results from 31 locations of the Bulli seam at West Cliff Colliery (Fredericks, 2008 and Black, 2012) showrd the average in situ permeability of coal as $2.2 \mathrm{mD}$, with the range extending from a low of $0.005 \mathrm{mD}$ to a high of $5.8 \mathrm{mD}$.

\section{CONCLUSIONS}

Permeability testing with the MFORR show that coal permeability decreases with increasing gas pressure. At higher gas pressures, coal permeability stays stable and changes little with changes in under differing operating range vertical stress conditions of the MFORR. 
Strain gauge results from the MFORR test clearly demonstrate the coal sample underwent negative volumetric changes or shrinkage with increased confinement pressures axially and laterally. The degree of the volumetric changes is found to be dependent on the level of the applied axial and lateral pressures or stresses.

Permeability testing using the high pressure conventional Triaxial Compression Apparatus can be used to study the relationship between axial and confining stress, gas pressure and coal permeability under triaxial condition. Coal sample permeability decreased with the increasing gas pressure. At higher gas pressures, coal permeability stays constant, a similar trend as with the permeability test with MFORR.

Under Triaxial Compression Apparatus, at each vertical stress, coal permeability decreases with the increasing horizontal stress. However, coal permeability decreases with the increasing vertical stress.

There is no significant mathematical difference between the two types of testing apparatus and calculation methods. Both permeability test results are comparable and tally's well with the Bulli coal seam tests result calculation from in situ condition. A permeability of $<2 \mathrm{mD}$ should be adopted under high triaxial stress conditions.

\section{ACKNOWLEDGMENT}

The financial support from University of Wollongong Scholarship and Scholarship from China Scholarship Council are gratefully acknowledged. The authors wish to thank the Illwarra coal mines, Australia for providing the Bulli seam coal samples used in this study. Also thanks are extended to the technical staff in University of Wollongong especially Alan Grant and Col Devenish.

\section{REFERENCES}

Aziz, N. and Li-Ming, W.: 1999, The effect of sorbed gas on the strength of coal - an experimental study. Geotechnical and Geological Engineering 17(3) (Honary eds: Indraratna and Aziz), 387-402. DOI: $10.1023 / \mathrm{A}: 1008995001637$

Black, D.J. and Aziz, N.I.: 2010, Impact of coal properties and operational factors on mine gas drainage, in Proceedings of the $10^{\text {th }}$ Underground Coal Operator's Conference COAL2010, University of Wollongong, (eds: N I Aziz and J A Nemcik), Wollongong, 11-12 February, 229-240.

Black, D.: 2012, Factors affecting the drainage of gas from coal and methods to improve drainage effectiveness. $\mathrm{PhD}$ thesis (University of Wollongong). $<$ http://www.uow.edu.au/eng/outburst/pdfs/D\%20Black\%20 PhD\%20Thesis.pdf>

Cui, X. and Busten, R.: 2006, Controls of coal fabric on coalbed gas production and compositional shift in both field production and canister desorption tests, SPE Journal, 111-119, (SPE-89035).

DOI: $10.2118 / 89035-\mathrm{PA}$
Fredericks, L.: 2008, Bulli seam permeability data files 2003 to 2006, BHP Billiton Illawarra Coal Exploration - Confidential Test Reports.

Gillies, A.D.S., Gray, I. and Ham, B.: 1995, Measurement of coal permeability using large samples. International Symposium-CUM-Workshop on Management and Control of High Gas Emissions and Outbursts in Underground Coal Mines, Wollongong, NSW, Australia, 317-322,

$<$ http://www.uow.edu.au/eng/outburst/pdfs/C3079\%20Final $\% 20$ Report.pdf $>$

Gray, I.: 1982, A study of seam gas drainage in Queensland, in Proceedings of the Symposium on Seam Gas Drainage with Particular Reference to the Working Seam, (ed: A J Hargraves), Australasian Institute of Mining and Metallurgy - Illawarra Branch, University of Wollongong, Wollongong, Australia, 11-14 May, 218-231.

Harpalani, S. and Schraufnagel, R.A.: 1990, Shrinkage of coal matrix with release of gas and its impact on permeability of coal, Fuel, 69, 551-556. DOI: 10.1016/0016-2361(90)90137-F

Hayes, P.J.: 1982. Factors affecting gas release from the working seam, in Proceedings of the seam gas drainage with particular reference to the working seam, organised by the Aus IMM -Illawarra branch, University of Wollongong, May, (Edit. A J Hargraves), 62-69,

$<$ http://www.uow.edu.au/eng/outburst/presentations publicat ions/ausimm_1982/P.J.Hayes.pdf>

Indraratna, B. and Haque, A.: 1999, Triaxial equipment for measuring the permeability nd strength of intact and fractured rocks, Geotechnique 49, 515-521. DOI: $10.1680 /$ geot.1999.49.4.515

Jackson, M.: 2004, Permeability testing procedure, BHP Billiton Illawarra Coal Exploration / Coal Bed Methane, Internal Operating Procedure, document reference - CBM-12-010.

Jasinge, D., Ranjith, P.G. and Choi, S.K.: 2011, Effects of effective stress changes on permeability of Latrobe valley brown coal. Fuel 90(3), 1292-1300. DOI: $10.1016 /$ j.fuel.2010.10.053

Jones, A.H. Ahmed, U., Abou-Sayed, A.S., Mahyera, A. and Sakashita, B.: 1982, Fractured vertical wells versus horizontal boreholes for methane drainage in advance of mining U.S. coals, in Proceedings of the Symposium on Seam Gas Drainage with Particular Reference to the Working Seam, (ed: A J Hargraves), Australasian Institute of Mining and Metallurgy Illawarra Branch, University of Wollongong, Wollongong, Australia, 172-201.

Lamarre, R.A.: 2007, Downhole geomechanical analysis of critical desorption pressure and gas content for carbonaceous reservoirs, SPE Annual Technical Workshop on Coalbed Methane, Society of Petroleum Engineers, Durango, Colorado, 31pp, (SPE-111091).

Lama, R.D.: 1995, Effect of stress, gas pressure and vacuum on permeability of bulli coal samples. International Symposium-CUM-Workshop on Management and Control of High Gas Emissions and Outbursts in Underground Coal Mines, Wollongong, NSW, Australia, 293-301, $<$ http://www.uow.edu.au/eng/outburst/pdfs/C3079\%20Final \%20Report.pdf>

Lingard, P.S., Phillips, H.R. and Doig, I.D.: 1982, The permeability of some Australian coals, Seam gas drainage with particular reference to the working 
seam, (Hargraves, A. J. (ed.), University of Wollongong, Wollongong, Australia, 70-80.

Nakajima, I., Asakura, Yang, Q. and Omai, T.: 1995, Effectof earth tempretureon gas permeability of stressed coal, International Symposium-CUMWorkshop on Management and Control of High Gas Emissions and Outbursts in Underground Coal Mines, Wollongong, NSW, Australia, 2323-330.

$<$ http://www.uow.edu.au/eng/outburst/pdfs/C3079\%20Final $\% 20$ Report.pdf $>$

Osisanya, S.A. and Schaffitzel, R.F.: 1996, A review of horizontal drilling and completion techniques for recovery of coalbed methane. SPE International Conference on Horizontal Well Technology, Society of Petroleum Engineers, Calgary, Canada, 13 pp, (SPE-37131).

Perera, M.S.A, Ranjith, P.G, Choi, S.K. and Airey, D.: 2011, The effects of sub-critical and super-critical carbon dioxide adsorption-induced coal matrix swelling on the permeability of naturally fractured black coal. Energy 36(11), 6442-6450.

DOI: $10.1016 /$ j.energy.2011.09.023

Sereshki, F.: 2005. Improving coal mine safety by identifying factors that influence the sudden release of gases in outburst prone zones. $\mathrm{PhD}$ thesis (University of Wollongong).

Zhang, L., Ren, T., Aziz, N., Nemcik, J. and Hyslop, A.: 2013, A critical analysis of gas data in relation to gas drainability in the Bulli seam, In proceedings $13^{\text {th }}$ Coal Operators Conference, Wollongong, NSW, Australia, February $14^{\text {th }}$ and $15^{\text {th }}$, (Eds, Aziz and Kininmonth), 299-305.

Zhang, L.: 2013, Study of coal sorption characteristcs and gas drainage in hard to drain seams, $\mathrm{PhD}$ thesis, University of Wollongong, NSW, Australia.

Zutshi, Z. and Harpalani, S.: 2005, Gas flow characterization of Illinois coal: assessment for recovery of coalbed methane and carbon sequestration potential, in Proceedings of the 2005 International Coalbed Methane Symposium, University of Alabama, Tuscaloosa, paper no. 0514, 10 pp. 